\title{
Cannabidiol modulates phosphorylated rpS6 signalling in a zebrafish model of tuberous sclerosis complex
}

Article

Accepted Version

Creative Commons: Attribution-Noncommercial-No Derivative Works 4.0

Serra, I., Scheldeman, C., Bazelot, M., Whalley, B. J., Dallas, M. L., De Witte, P. A. M. and Williams, C. M. (2019)

Cannabidiol modulates phosphorylated rpS6 signalling in a zebrafish model of tuberous sclerosis complex. Behavioural Brain Research, 363. pp. 135-144. ISSN 0166-4328 doi: https://doi.org/10.1016/j.bbr.2019.01.040 Available at https://centaur.reading.ac.uk/81954/

It is advisable to refer to the publisher's version if you intend to cite from the work. See Guidance on citing.

To link to this article DOI: http://dx.doi.org/10.1016/j.bbr.2019.01.040

Publisher: Elsevier

All outputs in CentAUR are protected by Intellectual Property Rights law, including copyright law. Copyright and IPR is retained by the creators or other copyright holders. Terms and conditions for use of this material are defined in the End User Agreement. 


\section{CentAUR}

Central Archive at the University of Reading

Reading's research outputs online 
1 TITLE: Cannabidiol modulates phosphorylated rpS6 signalling in a zebrafish model of Tuberous Sclerosis Complex

\section{AUTHOR INFORMATION:}

Ines Serra ${ }^{\mathrm{a}, \mathrm{b}}$, Chloë Scheldeman ${ }^{\mathrm{c}, \mathrm{d} 1}$, Michael Bazelot ${ }^{\mathrm{e}}$, Benjamin J. Whalley ${ }^{\mathrm{b}, \mathrm{e}}$, Mark

L. Dallas ${ }^{\mathrm{b}}$, Peter A. M. de Wittec, Claire M. Williams ${ }^{\mathrm{a}}$

6

$7 \quad{ }^{a}$ School of Psychology and Clinical Language Sciences, University of Reading, Reading, UK

8

9

${ }^{\mathrm{b}}$ School of Pharmacy, University of Reading, Reading, UK m.dallas@reading.ac.uk

${ }^{c}$ Laboratory for Molecular Biodiscovery, Department of Pharmaceutical and

Pharmacological Sciences, University of Leuven, Leuven, Belgium

CORRESPONDING AUTHOR:

Claire M. Williams

claire.williams@reading.ac.uk

School of Psychology \& Clinical Language Sciences, University of Reading, Earley Gate,

Whiteknights, RG6 6AL, United Kingdom

\footnotetext{
${ }^{1}$ Present address
} 
FUNDING:

27 The work reported here was funded in part by grants to CMW and MD from GW Research

Ltd and to PAMW by the European Union Seventh Framework Programme FP7/2007-2013 under the project EPISTOP (grant agreement nr: 602391).

\section{CONFLICT OF INTERESTS:}

32

The original study concept was discussed with GW Research Ltd, although all subsequent study design, data collection, analysis and interpretation were conducted independently by the authors. The report was approved by the sponsor company prior to submission, and the authors retain full control of all primary data.

\section{ABSTRACT:}

Tuberous sclerosis complex (TSC) is a rare disease caused by mutations in the TSC1 or TSC2 genes and is characterized by widespread tumour growth, intractable epilepsy, cognitive deficits and autistic behaviour. CBD has been reported to decrease seizures and inhibit tumour cell progression, therefore we sought to determine the influence of CBD on TSC pathology in zebrafish carrying a nonsense mutation in the $t s c 2$ gene.

CBD treatment from 6 to 7 days post-fertilization (dpf) induced significant anxiolytic actions without causing sedation. Furthermore, CBD treatment from 3 dpf had no impact on $t s c 2^{-/-}$larvae motility nor their survival. CBD treatment did, however, reduce the number of phosphorylated rpS6 positive cells, and their cross-sectional cell size. This suggests a CBD mediated suppression of mechanistic target of rapamycin (mTOR) activity in the $t s c 2^{-/-}$larval brain. 
Taken together, these data suggest that CBD selectively modulates levels of phosphorylated rpS6 in the brain and additionally provides an anxiolytic effect. This is pertinent given the alterations in mTOR signalling in experimental models of TSC. Additional work is necessary to identify upstream signal modulation and to further justify the use of CBD as a possible therapeutic strategy to manage TSC.

\section{KEYWORDS:}

tuberous sclerosis complex; cannabidiol; cannabinoids; zebrafish; rpS6; mTOR.

\section{ABBREVIATIONS ${ }^{2}$}

\section{INTRODUCTION:}

Tuberous sclerosis complex (TSC) is a rare genetic disease caused by a mutation in the $T S C 1$ or TSC2 genes, coding for the proteins hamartin and tuberin, respectively [1]. TSC1 and TSC2 form an inhibitory complex with GTPase-activating protein (GAP) activity. This keeps Ras homolog enriched in brain (Rheb) bound to GDP and in an inactive form, preventing downstream phosphorylation of mechanistic target of rapamycin (mTOR). In humans and animal models of TSC, mutations in TSC1 or TSC2 impair the inhibitory function of the complex, allowing activation of Rheb by GTP and constitutive activation of $\operatorname{mTOR}[2,3]$

mTOR is a major convergence point for extracellular signalling, through regulation of anabolic processes such as transcription and translation [4]. This regulation of protein synthesis by mTOR extends throughout the mammalian lifespan and is crucial for central

\footnotetext{
${ }^{2}$ CBD cannabidiol; days post-fertilization; mTOR mechanistic target of rapamycin; rpS6 ribosomal protein 6; TSC Tuberous sclerosis complex; TR Touch-response
} 
nervous system (CNS) development, where it controls soma size, dendritic arborisation, cortical lamination, and plasticity [5,6].

Overactivation of mTOR is evident in the majority of TSC patients that present with benign tumours in several organs, such as skin, kidneys and brain [6,7]. These often require surgical treatment and are a major source of morbidity for patients [8]. Furthermore, disruption of mTOR function in TSC also leads to neurological and neuropsychiatric complications in $85 \%$ of patients. Brain lesions such as cortical dysplasia, subependymal nodules and tubers are present in $70-90 \%$ of these patients [1]. Importantly, tubers and the perituberal tissue have long been associated with epilepsy, the most common neurological manifestation in TSC. In fact, $80-96 \%$ of patients have epilepsy with two thirds refractory to existent therapies [1,9]. Failure to control seizures in TSC patients is highly correlated with an early onset of seizures, before the age of 1 year old, in the form of focal epilepsy and infantile spasms [10]. Epilepsy is frequently associated with tuberous sclerosis associated neuropsychiatric disorders (TAND), such as autism spectrum disorder, present in $40-50 \%$ of patients, and intellectual disability, present in $30 \%[9,11]$. The importance of seizure control is further reinforced by its positive impact on developmental outcomes and quality of life assessments [12,13]. Nonetheless, despite the availability of some treatment options, due to the high heterogeneity of manifestations and TSC phenotype, not all individuals respond to the currently available therapies and new options are needed to attend to the patients' needs $[10,14,15]$

Given that a vast array of different systems and organs are affected by TSC, treatment typically requires a poly-pharmacological approach. mTOR inhibitors, such as rapamycin and everolimus, are current first-line treatments to control the growth of asymptomatic lesions. Epilepsy treatment can include one or multiple anti-epileptic drugs (AEDs), especially if resistance is present. Vigabatrin, which has been proposed to modulate both GABA levels 
and the mTOR pathway [16], displays good efficacy in TSC and is the most commonly used AED in these patients $[9,17]$. Regarding TAND, no specific therapies are yet approved, although early-intervention neuropsychiatric programmes, seizure control and mTOR inhibition have shown to contribute to cognitive improvement $[9,18]$.

There is growing evidence to support the use of cannabidiol (CBD), the most abundant non-euphoric phytocannabinoid derived from Cannabis sativa [19], in the management of seizures [20]. Previous in vitro and in vivo studies have demonstrated the efficacy of CBD in reducing the frequency and severity of seizures, in different models of epilepsy [21,22]. More recently, two clinical trials provided evidence of a CBD induced reduction in the median frequency of convulsive seizures and of drop seizures, in Dravet Syndrome (DS) and Lennox-Gastaut Syndrome, respectively [23,24]. Additionally, an expanded-access study of CBD for patients with TSC also suggested an effect of CBD in reducing seizure frequency in this population [25]. CBD has also shown beneficial effects in tumour studies. In vitro reduction of cellular viability and proliferation was demonstrated in both tumour cell lines [26-31] and primary tumour cells [26], whilst reducing tumour volume [26,28,31] and metastasis in vivo [31-33]. Importantly, CBD has been shown to modulate some components of the mTOR pathway [30,31,34-38], however there is a divergence in the reported effects with evidence from the cancer field supporting a CBD inhibition of mTOR, while epilepsy studies indicate an activation of mTOR. Therefore, in the complex pathology of TSC, the modulation of mTOR signalling via CBD is unclear.

Several animal models are available for the study of TSC, although none of these fully replicates all features of the human disease [39]. Mammalian models include the Eker rat, with a spontaneous $T s c 2$ mutation, and several conditional knockout mice which allow biallelic inactivation of $T s c 1$ or $T s c 2$ in a cell specific manner $[39,40]$. Non-mammalian models are also widely used, as it is the case of Saccharomyces cerevisiae, Drosophila and 
zebrafish [41]. The zebrafish model of TSC used here carries the nonsense $v u 242$ mutation in the $t s c 2$ gene [42]. This renders tuberin inactive as it lacks the functional GAP domain. Several human-like disease features, such as increased phosphorylation of rpS6, a protein downstream of mTOR and often used as a readout of mTORC1's activity [43,44], increased cell size and early death of homozygotes, are present in this model [42]. More recently, an mTOR-dependent disruption of locomotor behaviour was also demonstrated in homozygous tcs $2^{-/-}$larvae [45]. Here we use a zebrafish model of TSC to examine the effects of CBD on the pathogenesis of TSC, including behavioural effects and ribosomal protein 6 phosphorylation. Our data highlights that CBD can modulate the mTOR pathway, through regulating the phosphorylation status of ribosomal protein 6 in a relevant model of TSC.

\section{MATERIALS AND METHODS:}

\section{Zebrafish Husbandry}

Zebrafish embryos, heterozygous for the $t s c 2^{\mathrm{vu} 242}$ mutation backcrossed with Tupfel longfin wild-type fish, were a generous gift of Malgorzata Wiweger, head of the Zebrafish Core Facility of the International Institute of Molecular and Cell Biology (Warsaw, Poland). The zebrafish model of TSC with a $t s c 2$ nonsense mutation $\left(t s c 2^{+/-}\right)$was previously described $[42,45]$. For this study, heterozygous $\left(t s c 2^{+/-}\right)$zebrafish were interbred to generate a mixture of wild-type $\left(t s c 2^{+/+}\right)$, heterozygous $\left(t s c 2^{+/}\right)$and homozygous $\left(t s c 2^{-/}\right)$larvae. Adult zebrafish were maintained at $28.5{ }^{\circ} \mathrm{C}$ in $\mathrm{UV}$-sterilized water on a $14 \mathrm{~h}$ light/10 $\mathrm{h}$ dark cycle under standard aquaculture conditions. Fertilized eggs were collected via natural spawning. Embryos and larvae $\left(t s c 2^{+/+}, t s c 2^{+/-}\right.$and $\left.t s c 2^{-I_{-}}\right)$were raised in embryo medium, containing 1.5 mM HEPES, pH 7.6, $17.4 \mathrm{mM} \mathrm{NaCl}, 0.21 \mathrm{mM} \mathrm{KCl}, 0.12 \mathrm{mM} \mathrm{MgSO} 4$ and $0.18 \mathrm{mM}$ $\mathrm{Ca}\left(\mathrm{NO}_{3}\right)_{2}$ in an incubator on a $14 \mathrm{~h} \mathrm{light} / 10 \mathrm{~h}$ dark cycle at $28.5{ }^{\circ} \mathrm{C}$. For all experiments described, larvae from 0 to 10 days post-fertilization (dpf) were used. All zebrafish 
experiments were approved by the Ethics Committee of the University of Leuven (Ethische

149 Commissie van de KU Leuven, approval number 061/2013) and by the Belgian Federal

Department of Public Health, Food Safety and Environment (Federale Overheidsdienst Volksgezondheid, Veiligheid van de Voedselketen en Leefmilieu, approval number LA1210199).

Maximum Tolerated Concentration (MTC)

6 dpf larvae were placed in a 24 well-plate (Corning Inc., New York, USA) and incubated with $396 \mu \mathrm{L}$ of swimming medium (Danieau's) and $4 \mu \mathrm{L}$ DMSO $(0.1$ or $1 \%)$ or CBD (GW Pharmaceuticals, Cambridge, UK) dissolved in DMSO. CBD was serial diluted and tested in concentrations ranging from $0.3 \mu \mathrm{M}$ to $125 \mu \mathrm{M}$. Plates were then transferred to a $37{ }^{\circ} \mathrm{C}$ incubator, in the dark, and larvae touch-response was tested after 1 and 24 hours of incubation. The MTC was defined as the highest concentration of CBD in DMSO that did not induce any observable signs of toxicity, such as necrosis, abnormal heart beat or loss of posture [46].

Locomotor Assay

The locomotor assay was performed as previously published [45]. In brief, $6 \mathrm{dpf}$ larvae were placed in a 24 well-plate, treated with Danieau's (called naïve larvae in the text), $0.1 \%$ DMSO or $1.25 \mu \mathrm{M}$ CBD in $0.1 \%$ DMSO, and incubated in dark for 24 hours. Plates were then removed from the incubator and placed in a Zebrabox, where movement of the larvae was automatically tracked and expressed in "actinteg" units (which is the sum of pixel changes detected during tracking). Here, fish were habituated for 10 minutes under both light and dark condition before being tracked for 5 minutes in both the light and dark conditions. To measure anxiogenic or anxiolytic effects due to compound administration, changes in the 
startle response upon light to dark transition were measured as previously published $[47,48]$. Touch response (TR) can be used to corroborate the MTC data as it is also a measure of larval peripheral reflexes [49]. Touch-response was tested, by touching the larvae's tail with a blunt needle, before and after tracking to monitor toxicity. The number of responding and non-responding larvae was registered. All researchers were blinded to genotype throughout behavioural testing and data analyses.

\section{Chronic Treatment and Survivability Assay}

Larvae were cultured in $200 \mu$ l of Danieau's, in a 96-well plate, and followed from 3 dpf until 10 dpf. Medium was changed every other day and $0.1 \%$ DMSO or $1.25 \mu$ M CBD in $0.1 \%$ DMSO added to the wells. The number of dead larvae was counted daily. At the end of the assay, the surviving larvae underwent the previously described locomotor assay.

\section{Genotyping}

Genotyping was conducted as previously published [45]. In summary, after sacrifice, zebrafish tails were collected and lysed for 3 hours, at $55{ }^{\circ} \mathrm{C}$, followed by 10 minutes at 95 ${ }^{\circ} \mathrm{C}$. PCR was performed on the lysates using Pfu polymerase (Thermo Scientific, UK), and the primers GTAACACAGAATCAGTGAATCGGA (forward primer) and CACACACAGAAAACACTTGAAGC (reverse primer). After PCR, samples underwent digestion with HpyCh4 IV (New England Biolabs, UK), for 1 hour, at $37{ }^{\circ} \mathrm{C}$, followed by fragment separation on a $2 \%$ agarose/ $0.5 \mu \mathrm{g} / \mathrm{mL}$ ethidium bromide gel, for 1 hour, at $110 \mathrm{~V}$. Due to post-mortem genotyping, and because a smaller ratio of $t s c 2^{-/-}$larvae is obtained compared to $t s c 2^{+/+}$and $t s c 2^{+/-}$, variation in group sizes exists throughout experiments.

\section{Immunohistochemistry (IHC)}



cold water. Heads were dissected and placed in $4 \%$ PFA for 48 hours, at $4{ }^{\circ} \mathrm{C}$, and then transferred into a $30 \%$ sucrose in PBS solution, at $4{ }^{\circ} \mathrm{C}$. These were then embedded in

201

202 optimum cutting temperature (OCT) compound and stored at $-80{ }^{\circ} \mathrm{C}$ until sectioned. $10 \mu \mathrm{m}$ sections were cut and collected onto microscope slides (SuperFrost Plus, Thermo Fisher Scientic, UK) and stored at $-80{ }^{\circ} \mathrm{C}$ until used.

For IHC, sections were incubated for 2 hours, at room temperature, in a $2 \%$ BSA, $10 \%$ horse serum and $0.05 \% \mathrm{TX}-100$ buffer, followed by an overnight incubation with a primary antibody against phosphorylated rpS6 (Ser235/236) (1:500; 2211 New England Biolabs, lot 0023, UK), in a $1 \%$ BSA and $0.05 \%$ TX-100 buffer, at $4{ }^{\circ} \mathrm{C}$. The next day, slides were rinsed in Tris-buffered saline (TBS) and incubated for 2 hours, at room temperature, with a goat anti-rabbit Alexa Fluor-647 secondary antibody (1:1000; A-21245 Thermo Fisher Scientific, lot 1805235, UK). After further rinses, sections were counterstained with DAPI (1:10 000; D1306 Thermo Fisher Scientific, UK) for 10 minutes, rinsed, dried, and mounted. For TUNEL staining $(1: 10 ; 12156792910$ Roche, lot 26320800, Sigma, UK), slides underwent the same buffer incubation procedure, excluding antibody incubation. After the final rinsing step, sections were incubated with TUNEL solution, in the dark, for 1 hour, at 37 ${ }^{\circ} \mathrm{C}$. Negative control was done by omitting the enzyme solution, while positive control was performed by previous incubation of sections with $5 \mathrm{mg} / \mathrm{mL}$ DNAse, for 10 minutes, at 37 ${ }^{\circ} \mathrm{C}$.

\section{Imaging and Image quantification}

Non-consecutive brain sections were imaged using a Zeiss AxioImager microscope. Exposure time was constant during image acquisition and background fluorescence was measured where the primary antibody or enzyme solution was omitted. Pictures were taken 
with a 20x objective using the AxioVision software. Original images were processed on Fiji Image $\mathbf{J}$ [50], and a region of interest (ROI) was freehand defined around the brain outline. The average intensity value for each ROI, in each picture, was measured as Intensity Arbitrary Units (IAU), following background subtraction for each picture. For cell counting, cells were considered positive if staining for both phosphorylated rpS6 and DAPI were clearly present. To measure cell size, a similar procedure was used, except five cells per picture were randomly selected and its cross-sectional area measured. A minimum of three animals per group and genotype were used, and 3-9 sections per animal were imaged and counted.

\section{Statistical Analysis}

Statistical analysis was performed in SPSS (IBM SPSS Statistics 22) and GraphPad Prism 5. Repeated measures two-way ANOVA was used to analyse data from the locomotor assay (genotype $\mathrm{x}$ treatment $\mathrm{x}$ exposure to light/dark) and phosphorylated rpS6 positive cell number (genotype $\mathrm{x}$ treatment $\mathrm{x}$ number positive cells/section), while a three-way ANOVA was used to analyse cell size (genotype $\mathrm{x}$ treatment $\mathrm{x}$ area of cells). Touch response (TR) (yes x no) was analysed by chi-square test and TUNEL positive cells with the Kruskal- Wallis test. Normality was assessed with the D'Agostino-Pearson omnibus test. Statistical testing was followed by Tukey or Bonferroni post-hoc tests.

Data are expressed as mean \pm SEM unless stated otherwise, and significant values were considered when $\mathrm{p} \leq 0.05$. All graphs were prepared with GraphPad Prism 5.

\section{RESULTS}

\subsection{CBD safety profile}



toxicity in the larvae, manifested by slow heartbeat, loss of posture and death. We then compared lower CBD concentrations $(0.3$ to $2.5 \mu \mathrm{M})$ in 0.1 or $1 \%$ DMSO. Here, the toxicity of CBD was reduced with the decrease in DMSO concentration from $1 \%$ to $0.1 \% .1 .25 \mu \mathrm{M}$ CBD in $0.1 \%$ DMSO was the highest CBD concentration in which all animals were alive after 24 hours and showed no signs of gross morphological abnormalities.

At a cellular level, toxicity signs were absent from the central nervous system, as indicated by a non-significant difference $(\mathrm{p}=1.0)$ in the number of apoptotic cells, as indicated by positive TUNEL staining (Fig. 1A-C). groups, administration of CBD from 6 to $7 \mathrm{dpf}$ did not affect the percentage of responders to touch $\left(\chi^{2}(2)=2.51, \mathrm{p}=0.3 ; 98.0 \%\right.$ for Danieau's, $\mathrm{n}=155 ; 95.8 \%$ for $0.1 \%$ DMSO, $\mathrm{n}=166$; 94.7\% for CBD, $\mathrm{n}=171$ ), as manifested by a non-significant difference in the TR of treated larvae (Fig.2A). properties of CBD $[23,25]$, we quantified the average swimming movement of larvae during the light period, as a reduction of overall exploratory movement can be used as a measure of sedation [51,52]. There were no statistically significant differences in the baseline

\subsection{Behavioural effects of CBD}

\subsubsection{CBD does not induce sedation in this zebrafish TSC model}

Next, we analysed larvae locomotor behaviour. To test the reported sedative behavioural exploration, between vehicle (0.1\% DMSO, 24h incubation) and CBD (1.25 $\mu \mathrm{M}$, 
24 hour incubation) treated larvae $(\mathrm{F}(1,322)=2.28, \mathrm{p}=0.1)$, in the $t s c 2^{+/+}(2275.9 \pm 190.3$ actinteg units, $\mathrm{n}=63$ vs $1914.7 \pm 289.1$ actinteg units, $\mathrm{n}=49, \mathrm{p}=0.873), t s c 2^{+/-}(2349.3 \pm 241.7$ actinteg units, $\mathrm{n}=76$ vs $1907.3 \pm 158.2$ actinteg units, $\mathrm{n}=92, \mathrm{p}=0.338)$ and tsc $^{-/-}(906.1 \pm$ 208.3 actinteg units, $\mathrm{n}=26$ vs $732.5 \pm 159.1$ actinteg units, $\mathrm{n}=22, \mathrm{p}=1.00$ ) groups, indicating that, under these conditions, CBD does not induce sedation (Fig. 2B).

\subsubsection{CBD reduces startle response of zebrafish larvae during the dark period}

Zebrafish larvae respond to changes in light beginning from $5 \mathrm{dpf}[53,54]$, and sudden changes from light to dark induce a startle response. Decreased locomotion after a startle stimulus is indicative of an anxiolytic effect [52,53,55-57]. Here, CBD (1.25 $\mu \mathrm{M}, 24$ hour incubation) treatment significantly reduced dark-induced movement compared to $0.1 \%$ DMSO $(\mathrm{F}(1,322)=7.26, \mathrm{p}=0.01)$ for all genotypes (Fig.2C).

\subsubsection{CBD does not rescue homozygote behavioural phenotype}

One of the features of this model is early death of $t s c 2^{-/-}$homozygotes, between 9 and $11 \mathrm{dpf}[42,45]$. This can also be seen in other TSC model organisms, such as mice and rats, which typically die at embryonic day 10-10.5 [58-60]. Additionally, reduced overall locomotion was recently shown in $t s c 2^{-/-}$larvae [45]. We therefore assessed the effects of long-term CBD incubation, from 3 to $10 \mathrm{dpf}$, on survivability and locomotion. No difference in the survival of $t s c 2^{-/-}$larvae $\left(\chi^{2}(1)=0.27, \mathrm{p}=0.6 ; \mathrm{n}=72\right.$ per group) (Fig.3A) nor swimming ability $(\mathrm{t}(1)=3.06, \mathrm{p}=0.2 ; 1459.8 \pm 366.8$ actinteg units, $\mathrm{n}=28$, vs $2875.6 \pm 520.1$ actinteg units, $\mathrm{n}=27$ ) (Fig.3B) was found between 0.1\% DMSO and CBD treated groups.

\subsection{CBD modulates phosphorylated rpS6}




\subsubsection{CBD reduces the number of phosphorylated rpS6 positive cells in $t s c^{+/+}$,} $t s c 2^{+/-}$and $t s c 2^{-/-}$larvae

We subsequently assessed the impact of CBD treatment upon rpS6 phosphorylation, which is increased in $t s c 2^{-/-}$zebrafish $[42,45]$. In the Danieau's group, we observed increased phosphorylated rpS6 immunofluorescence in $t s c 2^{-/-}$zebrafish brains $(18.0 \pm 2.0$ IAU), compared to the $t s c 2^{+/+}(8.0 \pm 1.1 \mathrm{IAU})$ and $t s c 2^{+/-}(8.4 \pm 1.3 \mathrm{IAU})$ groups, confirming what others had previously shown $[42,45]$. Unexpectedly, an overall increase in phosphorylated rpS6 intensity was also observed in sections from 0.1\% DMSO incubated larvae $(10.72 \pm 1.7$, for $t s c 2^{+/+}, \quad 6.0 \pm 0.6$, for $t s c 2^{+/-}, \quad 12.1 \pm 1.4 \mathrm{IAU}$, for $t s c 2^{-{ }^{--}}$), while reduced immunofluorescence was found in the CBD groups $\left(4.5 \pm 0.6\right.$, for $t s c 2^{+/+}, 6.0 \pm 0.9$, for $t s c 2^{+/-}$ , $11.09 \pm 1.2$, for $t s c 2^{-/-}$IAU) (Fig.4A).

Section size was accounted for by prior analysis of total brain section size. This revealed no significant differences between genotypes or treatments (Fig.1D).

Quantification of phosphorylated rpS6 positive cells revealed a significant main effect of treatment, indicating that $0.1 \%$ DMSO on its own increased the number of phosphorylated rpS6 positive cells per section (187.1 \pm 13.6 cells per section) compared to Danieau's (116.1 \pm 11.7 cells per section) and to CBD (42.8 \pm 13.0 cells per section). Considering genotypespecific effects, further analysis revealed that $0.1 \%$ DMSO significantly increased the number of phosphorylated rpS6 positive cells in the $t s c 2^{+/+}$group, while this increase was not evident in the $t s c 2^{+/-}$and $t s c 2^{-/-}$group. CBD suppressed the DMSO-induced increase in the number of phosphorylated rpS6 positive cells across all genotypes $(184.1 \pm 26.0, n=12$ vs $10.7 \pm 19.6, \mathrm{n}=21, \mathrm{p}<0.001 ; 97.7 \pm 23.2, \mathrm{n}=15$ vs $3.2 \pm 26.0, \mathrm{n}=12, \mathrm{p}=0.03 ; 279.3 \pm 21.2$ $\mathrm{n}=18$ vs $114.7 \pm 21.2, \mathrm{n}=18 \mathrm{p}<0.001 ;$ for $t s c 2^{+/+}, t s c 2^{+/-}$and $t s c 2^{-/-}$larvae, respectively) (Fig.4C). 

immunoreactivity in larval brain. cells.

\section{DISCUSSION}



recognised as the basis for pharmacology intervention in a host of diseases $[19,20,62]$. Here we examine the effects of $\mathrm{CBD}$ to modulate aberrant mTORC1 signalling in zebrafish carrying a $t s c 2$ mutation.

Anxiety is a TSC-associated neuropsychiatric disorder and evidence indicates altered serotonin signalling as a biological mechanism [65-68]. One of the proposed targets for CBD is the $5-\mathrm{HT}_{1 \mathrm{~A}}$ receptor, where it has been shown to bind and to have agonist functions at concentrations $\geq 10 \mu \mathrm{M}$ in vitro $[73,74]$. Several serotonin receptors, orthologues to human receptors, have been shown to be expressed in zebrafish larvae, including the 5- $\mathrm{HT}_{1 \mathrm{~A}}$ receptor [72,79]. This is pertinent to the current study with the 5-HT $1 \mathrm{~A}$ receptor a proposed site of action for $\mathrm{CBD}[73,74]$. However, contrasting with the function of mammalian 5-HT $1 \mathrm{~A}$ receptors, the role of these receptors on anxiety behaviour in zebrafish is less defined. For example, extracellular serotonin content has been reported to have contrasting effects on anxiety in the same adult zebrafish species [72,80]. Larvae, in contrast to their adult counterparts, exhibit a transient elevation in motor activity in response to sudden onset of darkness $[53,64,81]$. Dark avoidance was shown to be modulated by anxiolytic drugs such as the 5-HT $\mathrm{H}_{1 \mathrm{~A}}$ agonist, buspirone, which increased dark preference patterns in zebrafish larvae [81].

Here we demonstrate a CBD induced reduction in startle response across genotypes However, a limitation of this model is that $t s c 2^{-/-}$larvae do not reach adulthood and, therefore, later behavioural testing cannot be performed to confirm an anxiolytic effect of CBD in this genotype. Nonetheless, further studies in $t s c 2^{+/-}$larvae could still be beneficial to elucidate possible effects of CBD in TSC, given the clinical TSC population are heterozygous [7]. 

serotonergic system is one such example and modulation here could provide control of other TSC features such as epilepsy, highly prevalent in TSC patients [17]. Evidence from epilepsy studies indicates that a reduction in serotonin concentration promotes seizures, while reduced serotonin binding to the $5-\mathrm{HT}_{1 \mathrm{~A}}$ receptor has been reported in epileptogenic foci $[83,84]$.

Studies also indicate that TSC patients present with increased tryptophan uptake localised to epileptic foci [85]. Given that CBD has been shown to reduce seizures in pathologies with different aetiologies $[23,25,89]$, and that $t s c 2^{-/-}$zebrafish, and other TSC models, have been shown to exhibit abnormal brain activity [45,90-92], it would be relevant to further study its role in the serotonergic system of TSC models.

A hallmark of TSC across all experimental models is an increase in mTOR activity $[1,3,5,6,42,45]$. Activation of mTOR leads to an increase in the ratio of downstream targets phosphorylated rpS6 /total rpS6, both in in vitro and in vivo models $[88,91,95,96]$. Therefore, phosphorylated rpS6 is often used as a read out of mTOR activation [97-99]. The reduction of rpS6 phosphorylation presented here is in line with published work where CBD treatment was found to modulate the mTOR pathway. In breast cancer cells, incubation with CBD has been observed to modulate Akt, a kinase upstream of mTOR, as well as 4E-BP1 and cyclin D $[98,106]$. In fact, we saw that Danieau's incubated animals showed a mutation-dependent increase in cell size, with $t s c 2^{-/-}$brain cells bigger than $t s c 2^{+/-}$, followed by $t s c 2^{+/+}$. These results are similar to previous work on this model, where a difference in size was found between $t s c 2^{+/+}$and $t s c 2^{-/-}$, in liver, brain, and spinal cord cells [42]. In accordance with a 
reduction in phosphorylated rpS6 positive cells there was a corresponding CBD effect on the cross-sectional area of brain cells. A comprehensive analysis of mTOR activity in phosphorylated rpS6 cells through enzymatic assay would definitely link the disruption in phosphorylated rpS6 to mTOR activity which remains unresolved in this current study.

However, contrasting effects on the mTOR signalling pathway by CBD have also been reported. For example, in amphetamine-sensitized rats, CBD reduced levels of pGSK$3 \beta$ and pAkt, but importantly it induced an increase of pmTOR and pS6K [35]. To further demonstrate the effect of CBD on mTOR specifically, this effect was reversed with the mTOR inhibitor, Torin 2 [35]. Additionally, administration of $10 \mathrm{mg} / \mathrm{kg}$ CBD to a mouse model of multiple sclerosis revealed increased pPI3K, pAkt, pmTOR and pS6K in spinal cord tissue. Importantly, in this model, basal levels of mTOR pathway activation were shown to be decreased [36]. Regarding the zebrafish model used here, we observed a decrease in phosphorylated rpS6, which could result from a reduction in mTOR activation. However, the survival and locomotion data regarding the chronically CBD-treated $t s c 2^{-/-}$larvae highlight that this modulation of mTOR was insufficient to impact these whole system outputs.

\section{CONCLUSION}

In the current study, using a TSC zebrafish model, we demonstrate that CBD was tolerable, while behavioural testing showed that CBD exhibited an anxiolytic profile without sedative effects. Additionally, we showed modulation of rpS6 manifested by the reduction of the number and size of phosphorylated rpS6 positive cells in the brain. Altogether, these data demonstrate that CBD modulates aberrant mTOR signalling in a model of TSC. It provides a rationale for further investigation into $\mathrm{CBD}$ as a therapeutic agent in diseases where mTOR signalling is disrupted. 


\section{BIBLIOGRAPHY}

420

421

422

423

424

425

426

427

428

429

430

431

432

433

434

435

436

437

438

439

440

441

442

443

444

445

446

447

448

449

450

451

452

453

454

455

456

457

458

459

460

[1] P. Curatolo, Mechanistic Target of Rapamycin (mTOR) in Tuberous Sclerosis Complex-Associated Epilepsy, Pediatr. Neurol. 52 (2015) 281-289. doi:10.1016/j.pediatrneurol.2014.10.028.

[2] C.C. Dibble, W. Elis, S. Menon, W. Qin, J. Klekota, J.M. Asara, P.M. Finan, D.J. Kwiatkowski, L.O. Murphy, B.D. Manning, TBC1D7 Is a Third Subunit of the TSC1TSC2 Complex Upstream of mTORC1, Mol. Cell. 47 (2012) 535-546. doi:10.1016/j.molcel.2012.06.009.

[3] M. Laplante, D.M. Sabatini, mTOR Signaling in Growth Control and Disease, Cell. 149 (2012) 274-293. doi:10.1016/j.cell.2012.03.017.

[4] S. Menon, C.C. Dibble, G. Talbott, G. Hoxhaj, A.J. Valvezan, H. Takahashi, L.C. Cantley, B.D. Manning, Spatial control of the TSC complex integrates insulin and nutrient regulation of mTORC1 at the lysosome, Cell. 156 (2014) 771-785. doi:10.1016/j.cell.2013.11.049.

[5] L. Swiech, M. Perycz, A. Malik, J. Jaworski, Role of mTOR in physiology and pathology of the nervous system, Biochim. Biophys. Acta - Proteins Proteomics. 1784 (2008) 116-132. doi:10.1016/j.bbapap.2007.08.015.

[6] P.B. Crino, The mTOR signalling cascade : paving new roads to cure neurological disease, Nat. Rev. Neurol. 12 (2016) 379-392. doi:10.1038/nrneurol.2016.81.

[7] P. Curatolo, R. Bombarderi, S. Jozwiak, Tuberous sclerosis, Lancet. (2008) 657-68. http://www.ncbi.nlm.nih.gov/entrez/query.fcgi?cmd=Retrieve \&db=PubMed\&dopt=Cit ation\&list_uids=1875767.

[8] P. Curatolo, R. Moavero, D. Roberto, F. Graziola, Genotype/Phenotype Correlations in Tuberous Sclerosis Complex, Semin. Pediatr. Neurol. 22 (2017) 259-273. doi:10.1016/j.spen.2015.10.002.

[9] P. Curatolo, R. Moavero, P.J. de Vries, Neurological and neuropsychiatric aspects of tuberous sclerosis complex., Lancet. Neurol. 14 (2015) 733-745. doi:10.1016/S14744422(15)00069-1.

[10] A. Jeong, J.A. Nakagawa, M. Wong, Predictors of Drug-Resistant Epilepsy in Tuberous Sclerosis Complex, J. Child Neurol. 32 (2017) 1092-1098. doi:10.1177/0883073817737446.

[11] P.J. de Vries, C.J. Howe, The tuberous sclerosis complex proteins - a GRIPP on cognition and neurodevelopment, Trends Mol. Med. 13 (2007) 319-326. doi:10.1016/j.molmed.2007.06.003.

[12] D.A. Krueger, A.A. Wilfong, K. Holland-Bouley, A.E. Anderson, K. Agricola, C. Tudor, M. Mays, C.M. Lopez, M.-O. Kim, D.N. Franz, Everolimus Treatment of Refractory Epilepsy in Tuberous Sclerosis Complex, Ann. Neurol. 74 (2013) 679-687. doi:10.1002/ana.23960.

[13] A.M. van Eeghen, C.J. Chu-Shore, M.B. Pulsifer, S.E. Camposano, E.A. Thiele, Cognitive and adaptive development of patients with tuberous sclerosis complex : A retrospective , longitudinal investigation, Epilepsy Behav. 23 (2012) 10-15. doi:10.1016/j.yebeh.2011.10.005. 
[14] A. Saxena, J.R. Sampson, Epilepsy in Tuberous Sclerosis: Phenotypes, Mechanisms, and Treatments., Semin. Neurol. 35 (2015) 269-76. doi:10.1055/s-0035-1552616.

[15] A. Vignoli, F. La Briola, K. Turner, G. Scornavacca, V. Chiesas, E. Zambrelli, A. Piazzini, M.N. Savini, R.M. Alfano, M.P. Canevini, Epilepsy in TSC : Certain etiology does not mean certain prognosis, Epilepsia. 54 (2013) 2134-2142. doi:10.1111/epi.12430.

[16] B. Zhang, S.S. McDaniel, N.R. Rensing, M. Wong, Vigabatrin Inhibits Seizures and mTOR Pathway Activation in a Mouse Model of Tuberous Sclerosis Complex, PLoS One. 8 (2013). doi:10.1371/journal.pone.0057445.

[17] J.C. Kingswood, G.B. D’Augères, E. Belousova, J.C. Ferreira, T. Carter, R. Castellana, V. Cottin, P. Curatolo, M. Dahlin, P.J. de Vries, M. Feucht, C. Fladrowski, G. Gislimberti, C. Hertzberg, S. Jozwiak, J.A. Lawson, A. Macaya, R. Nabbout, F. O’Callaghan, M.P. Benedik, J. Qin, R. Marques, V. Sander, M. Sauter, Y. Takahashi, R. Touraine, S. Youroukos, B. Zonnenberg, A.C. Jansen, TuberOus SClerosis registry to increase disease Awareness (TOSCA) -- baseline data on 2093 patients, Orphanet J. Rare Dis. 12 (2017) 1-13. doi:10.1186/s13023-016-0553-5.

[18] T.T. Gipson, M. V Johnston, New insights into the pathogenesis and prevention of tuberous sclerosis-associated neuropsychiatric disorders ( TAND ) [ version 1 ; referees : 3 approved ] Referee Status :, F1000Research. 6 (2017) 1-7. doi:10.12688/f1000research.11110.1.

[19] C. Ibeas Bih, T. Chen, A.V.W. Nunn, M. Bazelot, M. Dallas, B.J. Whalley, Molecular Targets of Cannabidiol in Neurological Disorders, Neurotherapeutics. (2015). doi:10.1007/s13311-015-0377-3.

[20] O. Devinsky, M.R. Cilio, H. Cross, J. Fernandez-Ruiz, J. French, C. Hill, R. Katz, V. Di Marzo, D. Jutras-Aswad, W.G. Notcutt, J. Martinez-Orgado, P.J. Robson, B.G. Rohrback, E. Thiele, B. Whalley, D. Friedman, Cannabidiol: Pharmacology and potential therapeutic role in epilepsy and other neuropsychiatric disorders, Epilepsia. 55 (2014) 791-802. doi:10.1111/epi.12631.

[21] B.D. Klein, C.A. Jacobson, C.S. Metcalf, M.D. Smith, K.S. Wilcox, A.J. Hampson, J.H. Kehne, Evaluation of Cannabidiol in Animal Seizure Models by the Epilepsy Therapy Screening Program ( ETSP ), Neurochem. Res. 42 (2017) 1939-1948. doi:10.1007/s11064-017-2287-8.

[22] L.R. Vilela, I. V Lima, É.B. Kunsch, H.P.P. Pinto, A.S. De Miranda, É.L.M. Leandro, A.C.P. de Oliveira, M.F.D. Moraes, A.L. Teixeira, F.A. Moreira, Anticonvulsant effect of cannabidiol in the pentylenetetrazole model: Pharmacological mechanisms, electroencephalographic profile, and brain cytokine levels, Epilepsy Behav. 75 (2017) 29-35. doi:10.1016/j.yebeh.2017.07.014.

[23] O. Devinsky, H. Cross, L. Laux, E. Marsh, I. Miller, R. Nabbout, I. Scheffer, E. Thiele, S. Wright, Trial of Cannabidiol for Drug-Resistant Seizures in the Dravet Syndrome, N. Engl. J. Med. 376 (2017) 2011-2020. doi:10.1056/NEJMoa1611618.

[24] E.A. Thiele, E.D. Marsh, J.A. French, M. Mazurkiewicz-Beldzinska, S.R. Benbadis, C. Joshi, P.D. Lyons, A. Taylor, C. Roberts, K. Sommerville, B. Gunning, J. Gawlowicz, P. Lisewski, M. Mazurkiewicz Beldzinska, K. Mitosek Szewczyk, B. Steinborn, M. Zolnowska, E. Hughes, A. McLellan, S. Benbadis, M. Ciliberto, G. Clark, D. Dlugos, F. Filloux, R. Flamini, J. French, M. Frost, S. Haut, C. Joshi, S. Kapoor, S. Kessler, L. 
Laux, P. Lyons, E. Marsh, D. Moore, R. Morse, V. Nagaraddi, W. Rosenfeld, L. Seltzer, R. Shellhaas, E. Thiele, L.L. Thio, D. Wang, A. Wilfong, Cannabidiol in patients with seizures associated with Lennox-Gastaut syndrome (GWPCARE4): a randomised, double-blind, placebo-controlled phase 3 trial, Lancet. 391 (2018) 10851096. doi:10.1016/S0140-6736(18)30136-3.

[25] E.J. Hess, K.A. Moody, A.L. Geffrey, S.F. Pollack, L.A. Skirvin, P.L. Bruno, J.L. Paolini, E.A. Thiele, Cannabidiol as a new treatment for drug-resistant epilepsy in tuberous sclerosis complex, Epilepsia. 57 (2016) 1617-1624. doi:10.1111/epi.13499.

[26] R. Ramer, K. Heinemann, J. Merkord, H. Rohde, A. Salamon, M. Linnebacher, B. Hinz, COX-2 and PPAR- gamma Confer Cannabidiol-Induced Apoptosis of Human Lung Cancer Cells, Mol. Cancer Ther. 12 (2012) 69-82. doi:10.1158/15357163.MCT-12-0335.

[27] M. Solinas, P. Massi, V. Cinquina, M. Valenti, D. Bolognini, M. Gariboldi, E. Monti, T. Rubino, D. Parolaro, Cannabidiol, a Non-Psychoactive Cannabinoid Compound, Inhibits Proliferation and Invasion in U87- MG and T98G Glioma Cells through a Multitarget Effect, PLoS Biol. 8 (2013). doi:10.1371/journal.pone.0076918.

[28] T. Fisher, H. Golan, G. Schiby, S. PriChen, R. Smoum, I. Moshe, N. Peshes-Yaloz, A. Castiel, D. Waldman, R. Gallily, R. Mechoulam, A. Toren, In vitro and in vivo efficacy of non-psychoactive cannabidiol in neuroblastoma, Curr. Oncol. 23 (2016) 15-22. doi:http://dx.doi.org/10.3747/co.23.2893.

[29] S.T. Lukhele, L.R. Motadi, Cannabidiol rather than Cannabis sativa extracts inhibit cell growth and induce apoptosis in cervical cancer cells, BMC Complement. Altern. Med. 16 (2016) 1-16. doi:10.1186/s12906-016-1280-0.

[30] A. Shrivastava, P.M. Kuzontkoski, J.E. Groopman, A. Prasad, Cannabidiol Induces Programmed Cell Death in Breast Cancer Cells by Coordinating the Cross-talk between Apoptosis and Autophagy, Mol. Cancer Ther. 10 (2011) 1161-1172. doi:10.1158/1535-7163.MCT-10-1100.

[31] M. Elbaz, M.W. Nasser, J. Ravi, N. a. Wani, D.K. Ahirwar, H. Zhao, S. Oghumu, A.R. Satoskar, K. Shilo, W.E. Carson, R.K. Ganju, Modulation of the tumor microenvironment and inhibition of EGF/EGFR pathway: Novel anti-tumor mechanisms of Cannabidiol in breast cancer, Mol. Oncol. 9 (2015) 906-919. doi:10.1016/j.molonc.2014.12.010.

[32] S.D. Mcallister, R. Murase, R.T. Christian, D. Lau, A.J. Zielinski, J. Allison, C. Almanza, A. Pakdel, J. Lee, C. Limbad, Y. Liu, R.J. Debs, D.H. Moore, P.-Y. Despres, Pathways mediating the effects of cannabidiol on the reduction of breast cancer cell proliferation, invasion, and metastasis, Breast Cancer Res. Treat. 129 (2011) 37-47. doi:10.1007/s10549-010-1177-4.

[33] R. Ramer, K. Bublitz, N. Freimuth, J. Merkord, H. Rohde, M. Haustein, P. Borchert, E. Schmuhl, M. Linnebacher, B. Hinz, Cannabidiol inhibits lung cancer cell invasion and metastasis via intercellular adhesion molecule-1, FASEB J. 26 (n.d.) 1535-1548. doi:10.1096/fj.11-198184.

[34] P.H. Gobira, L.R. Vilela, B.D.C. Gonçalves, R.P.M. Santos, A.C. de Oliveira, L.B. Vieira, D.C. Aguiar, J. a. Crippa, F. a. Moreira, Cannabidiol, a Cannabis sativa constituent, inhibits cocaine-induced seizures in mice: Possible role of the mTOR pathway and reduction in glutamate release, Neurotoxicology. 50 (2015) 116-121. 
doi:10.1016/j.neuro.2015.08.007.

[35] J. Renard, M. Loureiro, L.G. Rosen, J. Zunder, C. De Oliveira, S. Schmid, W.J. Rushlow, S.R. Laviolette, Cannabidiol Counteracts Amphetamine-Induced Neuronal and Behavioral Sensitization of the Mesolimbic Dopamine Pathway through a Novel mTOR/p70S6 Kinase Signaling Pathway, J. Neurosci. 36 (2016) 5160-5169. doi:10.1523/JNEUROSCI.3387-15.2016.

[36] S. Giacoppo, F. Pollastro, G. Grassi, P. Bramanti, E. Mazzon, Target regulation of $\mathrm{PI} 3 \mathrm{~K} / \mathrm{Akt} / \mathrm{mTOR}$ pathway by cannabidiol in treatment of experimental multiple sclerosis, Fitoterapia. 116 (2017) 77-84. doi:10.1016/j.fitote.2016.11.010.

[37] N. Kalenderoglou, T. Macpherson, K.L. Wright, Cannabidiol Reduces Leukemic Cell Size - But Is It Important ?, Front. Pharmacol. 8 (2017) 1-9. doi:10.3389/fphar.2017.00144.

[38] A.J. Sales, M. V Fogaça, A.G. Sartim, V.S. Pereira, G. Wegener, F.S. Guimarães, S.R.L. Joca, Cannabidiol Induces Rapid and Sustained Antidepressant-Like Effects Through Increased BDNF Signaling and Synaptogenesis in the Prefrontal Cortex, Mol. Neurol. (2018).

[39] G.L. Holmes, C.E. Stafstrom, Tuberous sclerosis complex and epilepsy: recent developments and future challenges., Epilepsia. 48 (2007) 617-630. doi:10.1111/j.1528-1167.2007.01035.x.

[40] M. Wong, Animal models of focal cortical dysplasia and tuberous sclerosis complex: Recent progress toward clinical applications, Epilepsia. 50 (2009) 34-44. doi:10.1111/j.1528-1167.2009.02295.x.

[41] P.L. Roubertoux, Organism Models of Autism Spectrum Disorders, Humana Press, New York, NY, 2015. doi:https://doi.org/10.1007/978-1-4939-2250-5.

[42] S.-H. Kim, C.K. Speirs, L. Solnica-Krezel, K.C. Ess, Zebrafish model of tuberous sclerosis complex reveals cell-autonomous and non-cell-autonomous functions of mutant tuberin., Dis. Model. Mech. 4 (2011) 255-267. doi:10.1242/dmm.005587.

[43] P. Curatolo, R. Moavero, J. van Scheppingen, E. Aronica, mTOR dysregulation and tuberous sclerosis-related epilepsy, Expert Rev. Neurother. 18 (2018) 185-201. doi:10.1080/14737175.2018.1428562.

[44] A. Biever, E. Valjent, E. Puighermanal, Ribosomal Protein S6 Phosphorylation in the Nervous System: From Regulation to Function, Front. Mol. Neurosci. 8 (2015) 1-14. doi:10.3389/fnmol.2015.00075.

[45] C. Scheldeman, J.D. Mills, A. Siekierska, I. Serra, D. Copmans, A.M. Iyer, B.J. Whalley, J. Maes, A.C. Jansen, L. Lagae, E. Aronica, P.A.M. De Witte, mTOR-related neuropathology in mutant tsc2 zebrafish : Phenotypic, transcriptomic and pharmacological analysis, Neurobiol. Dis. 108 (2017) 225-237. doi:10.1016/j.nbd.2017.09.004.

[46] A.M. Orellana-Paucar, A.S.K. Serruys, T. Afrikanova, J. Maes, W. De Borggraeve, J. Alen, F. Le??n-Tamariz, I.M. Wilches-Ariz??bala, A.D. Crawford, P.A.M. de Witte, C. V. Esguerra, Anticonvulsant activity of bisabolene sesquiterpenoids of Curcuma longa in zebrafish and mouse seizure models, Epilepsy Behav. 24 (2012) 14-22. doi:10.1016/j.yebeh.2012.02.020. 
[47] Q. Li, J. Lin, Y. Zhang, X. Liu, X.Q. Chen, M.Q. Xu, L. He, S. Li, N. Guo, Differential behavioral responses of zebrafish larvae to yohimbine treatment, Psychopharmacology (Berl). 232 (2015) 197-208. doi:10.1007/s00213-014-3656-5.

[48] Y. Ji, J. Lin, X. Peng, X. Liu, F. Li, Y. Zhang, N. Guo, Q. Li, Behavioural responses of zebrafish larvae to acute ethosuximide exposure, Behav. Pharmacol. 28 (2017) 428440. doi:10.1097/FBP.0000000000000312.

[49] V. Carmean, A.B. Ribera, Genetic Analysis of the Touch Response in Zebrafish (Danio rerio), Int. J. Comp. Psychol. 23 (2010) 91-102.

[50] J. Schindelin, I. Arganda-carreras, E. Frise, V. Kaynig, M. Longair, T. Pietzsch, S. Preibisch, C. Rueden, S. Saalfeld, B. Schmid, J. Tinevez, D.J. White, V. Hartenstein, K. Eliceiri, P. Tomancak, A. Cardona, Fiji : an open-source platform for biologicalimage analysis, 9 (2012). doi:10.1038/nmeth.2019.

[51] K. Vermoesen, A.S.K. Serruys, E. Loyens, T. Afrikanova, A. Massie, A. Schallier, Y. Michotte, A.D. Crawford, C. V. Esguerra, P.A.M. de Witte, I. Smolders, R. Clinckers, Assessment of the convulsant liability of antidepressants using zebrafish and mouse seizure models, Epilepsy Behav. 22 (2011) 450-460. doi:10.1016/j.yebeh.2011.08.016.

[52] S.J. Schnörr, P.J. Steenbergen, M.K. Richardson, D.L. Champagne, Measuring thigmotaxis in larval zebrafish, Behav. Brain Res. 228 (2012) 367-374. doi:10.1016/j.bbr.2011.12.016.

[53] H.A. Burgess, M. Granato, Modulation of locomotor activity in larval zebrafish during light adaptation, J. Exp. Biol. 210 (2007) 2526-2539. doi:10.1242/jeb.003939.

[54] J. Ramcharitar, R.M. Ibrahim, Ethanol modifies zebrafish responses to abrupt changes in light intensity, J. Clin. Neurosci. 20 (2013) 476-477.

doi:10.1016/j.jocn.2012.09.010.

[55] L.D. Ellis, J. Seibert, K.H. Soanes, Distinct models of induced hyperactivity in zebrafish larvae, Brain Res. 1449 (2012) 46-59. doi:10.1016/j.brainres.2012.02.022.

[56] X. Peng, J. Lin, Y. Zhu, X. Liu, Y. Zhang, Y. Ji, X. Yang, Y. Zhang, N. Guo, Q. Li, Anxiety-related behavioral responses of pentylenetetrazole-treated zebrafish larvae to light-dark transitions, Pharmacol. Biochem. Behav. 145 (2016) 55-65. doi:10.1016/j.pbb.2016.03.010.

[57] B.B. Griffiths, P.J. Schoonheim, L. Ziv, L. Voelker, H. Baier, E. Gahtan, A zebrafish model of glucocorticoid resistance shows serotonergic modulation of the stress response, Front. Behav. Neurosci. 6 (2012) 1-10. doi:10.3389/fnbeh.2012.00068.

[58] O. Hino, A.J. Klein-Szanto, J.J. Freed, J.R. Testa, D.Q. Brown, M. Vilensky, R.S. Yeung, K.D. Tartof, A.G. Knudson, Spontaneous and radiation-induced renal tumors in the Eker rat model of dominantly inherited cancer, Proc. Natl. Acad. Sci. . 90 (1993) 327-331. http://www.pnas.org/content/90/1/327.abstract.

[59] T. Kobayashi, O. Minowa, J. Kuno, H. Mitani, O. Hino, T. Noda, Renal Carcinogenesis, Hepatic Hemangiomatosis, and Embryonic Lethality Caused by a Germ-Line Tsc2 Mutation in Mice, Cancer Res. 59 (1999) 1206-1211.

[60] T. Kirschstein, R. Kohling, Animal models of tumour-associated epilepsy, J. Neurosci. Methods. 260 (2015) 109-117. doi:10.1016/j.ijdevneu.2011.12.001.

[61] O. Meyuhas, A. Dreazen, Chapter 3 Ribosomal Protein S6 Kinase. From TOP mRNAs 
to Cell Size, 1st ed., Elsevier Inc., 2009. doi:10.1016/S1877-1173(09)90003-5.

[62] E.M. Blessing, M.M. Steenkamp, J. Manzanares, C.R. Marmar, Cannabidiol as a Potential Treatment for Anxiety Disorders, Neurotherapeutics. 12 (2015) 825-836. doi:10.1007/s13311-015-0387-1.

[63] K. Iffland, F. Grotenhermen, An Update on Safety and Side Effects of Cannabidiol : A Review of Clinical Data and Relevant Animal Studies, Cannabis Cannabinoid Res. 2 (2017) 139-154. doi:10.1089/can.2016.0034.

[64] D.R. Carty, C. Thornton, J.H. Gledhill, K.L. Willett, Developmental Effects of Cannabidiol and $\Delta$ 9-Tetrahydrocannabinol in Zebrafish, Toxicol. Sci. 0 (2017) 1-9. doi:10.1093/toxsci/kfx232.

[65] A.M. Rentz, A.M. Skalicky, Z. Liu, J.W. Wheless, D.W. Dunn, M.D. Frost, J. Nakagawa, M. Magestro, J. Prestifilippo, Tuberous Sclerosis Somplex: A Survey of Health Care Resource Use and Health Burden., Pediatr. Neurol. 52 (2015) 435-441. doi:10.1016/j.pediatrneurol.2014.11.013.

[66] J. Solati, A.A. Salari, A. Bakhtiari, 5HT1Aand 5HT1Breceptors of medial prefrontal cortex modulate anxiogenic-like behaviors in rats, Neurosci. Lett. 504 (2011) 325-329. doi:10.1016/j.neulet.2011.09.058.

[67] T. Bordukalo-Niksic, G. Mokrovic, J. Stefulj, M. Zivin, B. Jernej, L. Cicin-Sain Lipa, 5HT-1A receptors and anxiety-like behaviours: Studies in rats with constitutionally upregulated/downregulated serotonin transporter, Behav. Brain Res. 213 (2010) 238245. doi:10.1016/j.bbr.2010.05.002.

[68] W. Koek, N.C. Mitchell, L.C. Daws, Biphasic effects of selective serotonin reuptake inhibitors on anxiety: rapid reversal of escitalopram's anxiogenic effects in the novelty-induced hypophagia test in mice?, Behav. Pharmacol. (2017) 1. doi:10.1097/FBP.0000000000000345.

[69] B. Bandelow, S. Michaelis, D. Wedekind, Treatment of anxiety disorders, Dialogues Clin. Neurosci. 19 (2017) 93-107.

[70] A.L. Garcia-Garcia, A. Newman-Tancredi, E.D. Leonardo, P5-HT1A receptors in mood and anxiety: recent insights into autoreceptor versus heteroreceptor function, Psychopharmacology (Berl). 231 (2014) 623-636. doi:10.1007/s00213-013-3389-x.

[71] A. Mendiguren, E. Aostri, J. Pineda, Regulation of noradrenergic and serotonergic systems by cannabinoids : relevance to cannabinoid-induced effects, Life Sci. 192 (2018) 115-127. doi:10.1016/j.lfs.2017.11.029.

[72] A.M. Herculano, C. Maximino, Serotonergic modulation of zebrafish behavior: Towards a paradox, Prog. Neuropsychopharmacol. Biol. Psychiatry. 55 (2014) 50-66. doi:10.1016/j.pnpbp.2014.03.008.

[73] E.B. Russo, A. Burnett, B. Hall, K.K. Parker, Agonistic Properties of Cannabidiol at 5HT1a Receptors, Neurochem. Res. 30 (2005) 1037-1043. doi:10.1007/s11064-0056978-1.

[74] W.H. Hind, T.J. England, S.E. O'Sullivan, Cannabidiol protects an in vitro model of the blood - brain barrier from oxygen-glucose deprivation via PPAR $\gamma$ and 5- HT 1A receptors, Br. J. Pharmacol. 173 (2016) 815-825. doi:10.1111/bph.13368.

[75] A.B. Sonego, F. V. Gomes, E.A. Del Bel, F.S. Guimaraes, Cannabidiol attenuates 
haloperidol-induced catalepsy and c-Fos protein expression in the dorsolateral striatum via 5-HT1A receptors in mice, Behav. Brain Res. 309 (2016) 22-28. doi:10.1016/j.bbr.2016.04.042.

[76] B.R. Chemel, B.L. Roth, B. Armbruster, V.J. Watts, D.E. Nichols, WAY-100635 is a potent dopamine D4 receptor agonist, Psychopharmacology (Berl). 188 (2006) 244251. doi:10.1007/s00213-006-0490-4.

[77] J.C. Martel, N. Leduc, A.M. Ormière, V. Faucillon, N. Danty, C. Culie, D. Cussac, A. Newman-Tancredi, WAY-100635 has high selectivity for serotonin 5-HT1Aversus dopamine D4receptors, Eur. J. Pharmacol. 574 (2007) 15-19. doi:10.1016/j.ejphar.2007.07.015.

[78] R. Linge, L. Jimenez-Sanchez, L. Campa, F. Pilar-Cuellar, R. Vidal, A. Pazos, A. Adell, A. Diaz, Cannabidiol induces rapid-acting antidepressant-like effects and enhances cortical 5-HT/glutamate neurotransmission: role of 5-HT1A receptors, Neuropharmacology. 103 (2016) 16-26. doi:10.1016/j.neuropharm.2015.12.017.

[79] J. Sourbron, H. Schneider, A. Kecskés, Y. Liu, M. Buening, L. Lagae, I. Smolders, P.A.M. De Witte, Serotonergic Modulation as Effective Treatment for Dravet syndrome in a Zebrafish Mutant Model, (2016). doi:10.1021/acschemneuro.5b00342.

[80] C. Maximino, B. Puty, R. Benzecry, J. Araújo, M.G. Lima, E.D.J. Batista, K.R. de M. Oliveira, M.E. Crespo-Lopez, A.M. Herculano, Role of serotonin in zebrafish (Danio rerio) anxiety: Relationship with serotonin levels and effect of buspirone, WAY 100635 , SB 224289 , fluoxetine and para-chlorophenylalanine (pCPA) in two behavioral models, Neuropharmacology. 71 (2013) 83-97. doi:10.1016/j.neuropharm.2013.03.006.

[81] P.J. Steenbergen, M.K. Richardson, D.L. Champagne, Patterns of avoidance behaviours in the light/dark preference test in young juvenile zebrafis : A pharmacological study, Behav. Brain Res. 222 (2011) 15-25. doi:10.1016/j.bbr.2011.03.025.

[82] M.A. Mori, E. Meyer, L.M. Soares, H. Milani, F.S. Guimaraes, R.M.W. de Oliveira, Cannabidiol reduces neuroinflammation and promotes neuroplasticity and functional recovery after brain ischemia, Prog. Neuropsychopharmacol. Biol. Psychiatry. 75 (2017) 94-105. doi:10.1016/j.pnpbp.2016.11.005.

[83] H.T. Chugani, D.C. Chugani, Imaging of Serotonin Mechanisms in Epilepsy, Epilepsy Curr. 5 (2005) 201-206. doi:10.1111/j.1535-7511.2005.00064.x.

[84] I. Sarikaya, PET studies in epilepsy, Am. J. Nucl. Med. Mol. Imaging. 5 (2015) 416430.

[85] H.T. Chugani, A.F. Luat, A. Kumar, R. Govindan, K. Pawlik, E. Asano, a-[11C]Methyl-L-tryptophan-PET in191 patients with tuberous sclerosis complex, Neurology. 81 (2013) 674-680. doi:10.1212/WNL.0b013e3182a08f3f.

[86] I. Davis, A. Liu, What is the tryptophan kynurenine pathway and why is it important to neurotherapeutics?, Expert Rev. Neurother. 15 (2015) 719-721. doi:10.1586/14737175.2015.1049999. What.

[87] D.C. Chugani, $\alpha$-methyl-L-tryptophan: mechanisms for tracer localization of epileptogenic brain regions, Biomark. Med. 5 (2011) 567-575.

doi:10.2217/bmm.11.73. 
[88] D.M. Talos, D.J. Kwiatkowski, K. Cordero, P.M. Black, F.E. Jensen, Cell-specific alterations of glutamate receptor expression in tuberous sclerosis complex cortical tubers, Ann. Neurol. 63 (2008) 454-465. doi:10.1002/ana.21342.

[89] J. French, E. Thiele, M. Mazurkiewicz-Beldzinska, S. Benbadis, E. Marsh, C. Joshi, C. Roberts, A. Taylor, K. Sommerville, Cannabidiol (CBD) significantly reduces drop seizure frequency in Lennox-Gastaut syndrome (LGS): results of a multi-center, randomized, double-blind, placebo controlled trial (GWPCARE4) (S21.001), Neurology. 88 (2017).

[90] L.-H. Zeng, N.R. Rensing, B. Zhang, D.H. Gutmann, M.J. Gambello, M. Wong, Tsc2 gene inactivation causes a more severe epilepsy phenotype than Tsc1 inactivation in a mouse model of Tuberous Sclerosis Complex, Hum. Mol. Genet. 20 (2011) 445-454. doi: $10.1093 / \mathrm{hmg} / \mathrm{ddq} 491$.

[91] D.M. Feliciano, T. Su, J. Lopez, J.-C. Platel, A. Bordey, Single-cell Tsc1 knockout during corticogenesis generates tuber-like lesions and reduces seizure threshold in mice., J. Clin. Invest. 121 (2011) 1596-1607. doi:10.1172/JCI44909.

[92] C. Fu, K.C. Ess, Conditional and domain-specific inactivation of the Tsc2 gene in neural progenitor cells, Genesis. 51 (2013) 284-292. doi:10.1002/dvg.22377.

[93] A.J. Hill, N. a. Jones, I. Smith, C.L. Hill, C.M. Williams, G.J. Stephens, B.J. Whalley, Voltage-gated sodium ( $\mathrm{NaV}$ ) channel blockade by plant cannabinoids does not confer anticonvulsant effects per se, Neurosci. Lett. 566 (2014) 269-274. doi:10.1016/j.neulet.2014.03.013.

[94] M.C. Pelz, K.D. Schoolcraft, C. Larson, M.G. Spring, H.H. López, Assessing the role of serotonergic receptors in cannabidiol's anticonvulsant efficacy, Epilepsy Behav. 73 (2017) 111-118. doi:10.1016/j.yebeh.2017.04.045.

[95] V. Ruppe, P. Dilsiz, C.S. Reiss, C. Carlson, O. Devinsky, D. Zagzag, H.L. Weiner, D.M. Talos, Developmental brain abnormalities in tuberous sclerosis complex : A comparative tissue analysis of cortical tubers and perituberal cortex, Epilepsia. 55 (2014) 539-550. doi:10.1111/epi.12545.

[96] P.T. Tsai, C. Hull, Y. Chu, E. Greene-Colozzi, A.R. Sadowski, J.M. Leech, J. Steinberg, J.N. Crawley, W.G. Regehr, M. Sahin, Autistic-like behaviour and cerebellar dysfunction in Purkinje cell Tsc1 mutant mice, Nature. 488 (2012) 647-651. doi:10.1038/nature11310.

[97] D.M. Feliciano, T. V. Lin, N.W. Hartman, C.M. Bartley, C. Kubera, L. Hsieh, C. Lafourcade, R.A. O'Keefe, A. Bordey, A circuitry and biochemical basis for tuberous sclerosis symptoms: From epilepsy to neurocognitive deficits, Int. J. Dev. Neurosci. 31 (2013) 667-678. doi:10.1016/j.ijdevneu.2013.02.008.

[98] S.F. Tavazoie, V. a Alvarez, D. a Ridenour, D.J. Kwiatkowski, B.L. Sabatini, Regulation of neuronal morphology and function by the tumor suppressors Tsc1 and Tsc2., Nat. Neurosci. 8 (2005) 1727-1734. doi:10.1038/nn1566.

[99] S.S. McDaniel, M. Wong, Therapeutic role of mammalian target of rapamycin (mTOR) inhibition in preventing epileptogenesis, Neurosci. Lett. 497 (2011) 231-239. doi:10.1016/j.neulet.2011.02.037.

[100] T.H. Chen, Y.H. Wang, Y.H. Wu, Developmental exposures to ethanol or dimethylsulfoxide at low concentrations alter locomotor activity in larval zebrafish: 
Implications for behavioral toxicity bioassays, Aquat. Toxicol. 102 (2011) 162-166. doi:10.1016/j.aquatox.2011.01.010. 


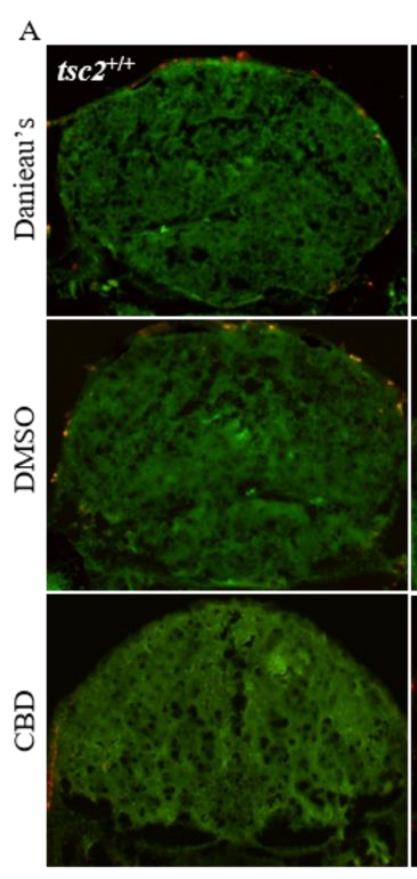

C

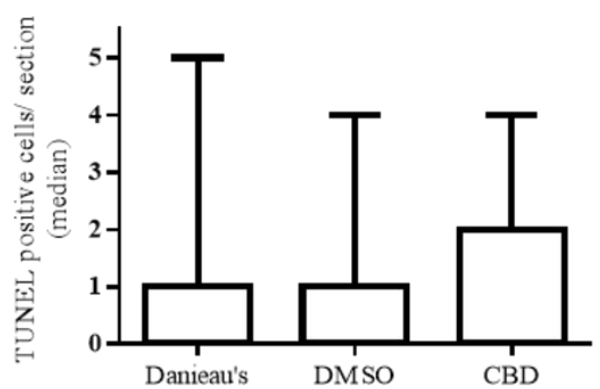

795

796
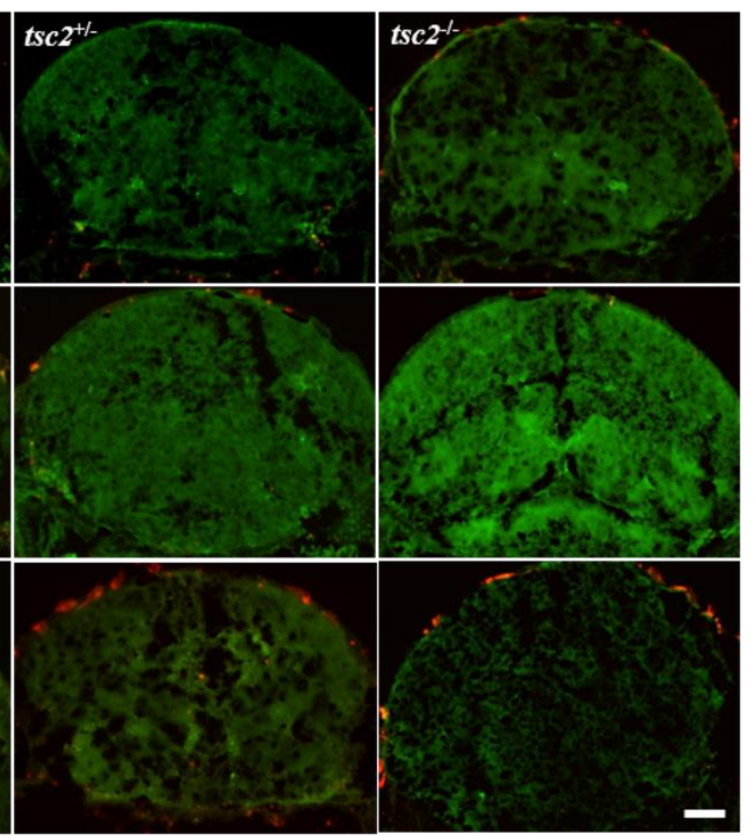

D
B

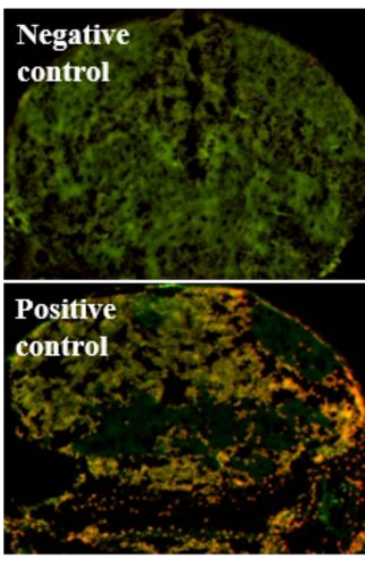

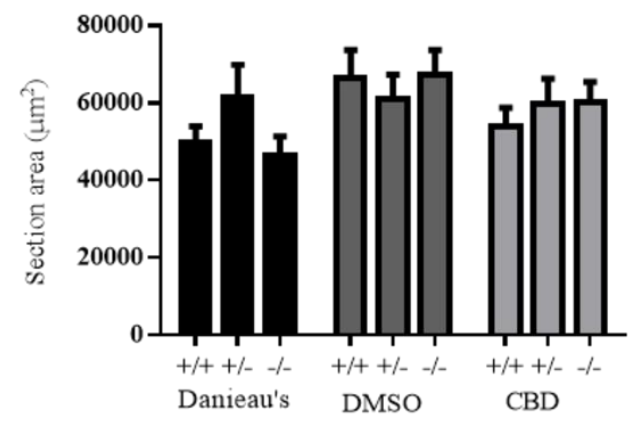

Figure 1: TUNEL labelling in the larval brain. (A) Representative pictures of the midbrain, for each treatment (Danieau's, 0.1\% DMSO and $1.25 \mu \mathrm{M} \mathrm{CBD}$ ) and genotype $\left(t s c 2^{+++}, t s c 2^{+--}\right.$and $t s c 2^{---}$), showing TUNEL positive cells in red and tissue autofluorescence in green. (B) Representative pictures of negative control, where enzyme solution was omitted, and of positive control, incubated with DNAse. (C) Median number of TUNEL positive cells in each section analysed, showing no statistical differences between treatment groups. ( $\mathrm{n}=3$ animals per group; $\mathrm{p}=1.0$. Data shown as median and minimum to maximum values) (D) Measurement of brain sections' area showed no significant differences in cross-sectional size, regardless of genotype $(\mathrm{F}(2,209)=0.30, \mathrm{p}=0.7)$ or treatment $(\mathrm{F}(2,209)=2.92, \mathrm{p}=0.06) \quad(\mathrm{n}=3-4$ animals per group, 15-30 sections per group measured). Scale $=50 \mu \mathrm{m}$. 
A
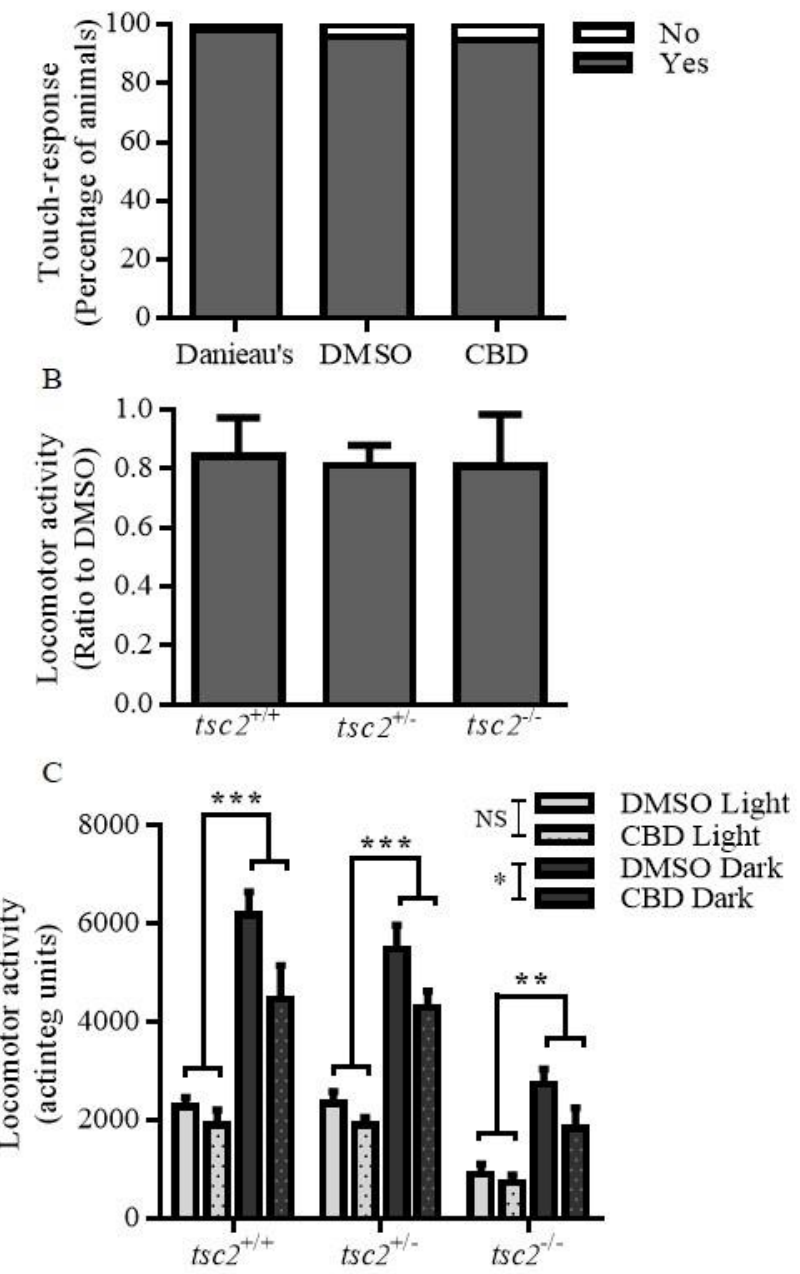

806

807 Figure 2: Treatment and genotype effects on larval locomotor behaviour: (A) Zebrafish touch-response is not altered in the presence of $0.1 \%$ DMSO nor CBD. Pooled data demonstrating no significant differences $\left(\chi^{2}(2)=2.5, p=0.3\right)$ between the percentage of zebrafish responding to touch in each treatment group ( $\mathrm{n}=152$ for Danieau's, $\mathrm{n}=165$ for $0.1 \%$ DMSO, n=163 for CBD). Values are shown as percentage of "Yes" or "No" response. (B) CBD has no effect on locomotor activity during light phase. Actinteg units normalised to vehicle $(0.1 \%$ DMSO) values demonstrate lack of effect on swimming activity under light $(\mathrm{F}(1,322)=2.28, \mathrm{p}=0.1)$, following exposure to CBD, indicating the absence of sedating properties $\left(\mathrm{n}=49-63\right.$ for $t s c 2^{+/+}, \mathrm{n}=76-92$ for $t s c 2^{+/-}, \mathrm{n}=22-26$ for $\left.t s c 2^{-/-}\right)$.

(C) CBD reduces zebrafish locomotor activity after a dark startling stimulus. Exposure to CBD during the light period (light bars) did not alter the average larval movement in any genotype. In the presence of a dark startling stimulus (dark bars), CBD induced a reduction of the average swimming activity $(\mathrm{F}(1,322)=7.26, \mathrm{p}=0.01) \quad$ Values are shown as mean actinteg units $\pm \mathrm{SEM}, * * * \mathrm{p}<0.001, * * \mathrm{p}<0.01$, $* \mathrm{p}<0.05$ 
A

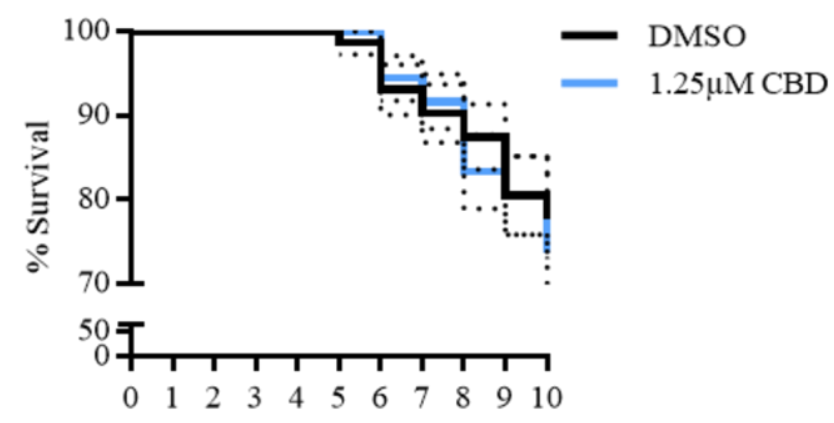

B

Days

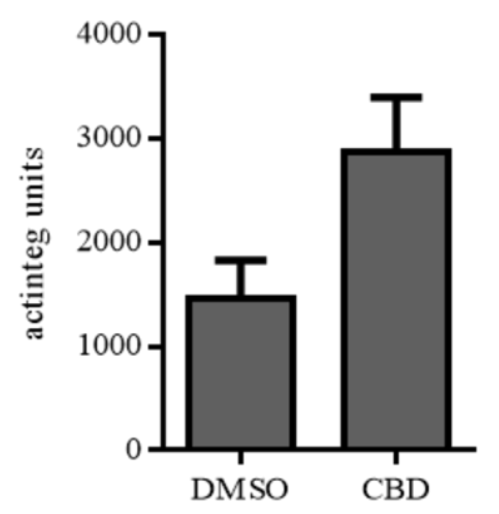

819

820

821 Figure 3: CBD does not improve $\boldsymbol{t s c}^{2 /-}$ larvae survival nor rescues movement deficits. (A) Treatment with

$8221.25 \mu \mathrm{M} \mathrm{CBD}$, from 3-10 dpf, did not alter $t s c 2^{-/-}$larvae survival compared to vehicle (n=72 per group). (B)

823 CBD treatment from 3-6 dpf CBD did not modulate movement deficits in $t s c 2^{-/-}$larvae $(\mathrm{t}(1)=3.06, \mathrm{p}=0.2 ; 1459.8$

$824 \pm 366.8$ vs $2875.6 \pm 520.1$ actinteg units, $n=28$ for $0.1 \%$ DMSO and $n=27$ for CBD, data presented as mean \pm 825 SEM).

826 


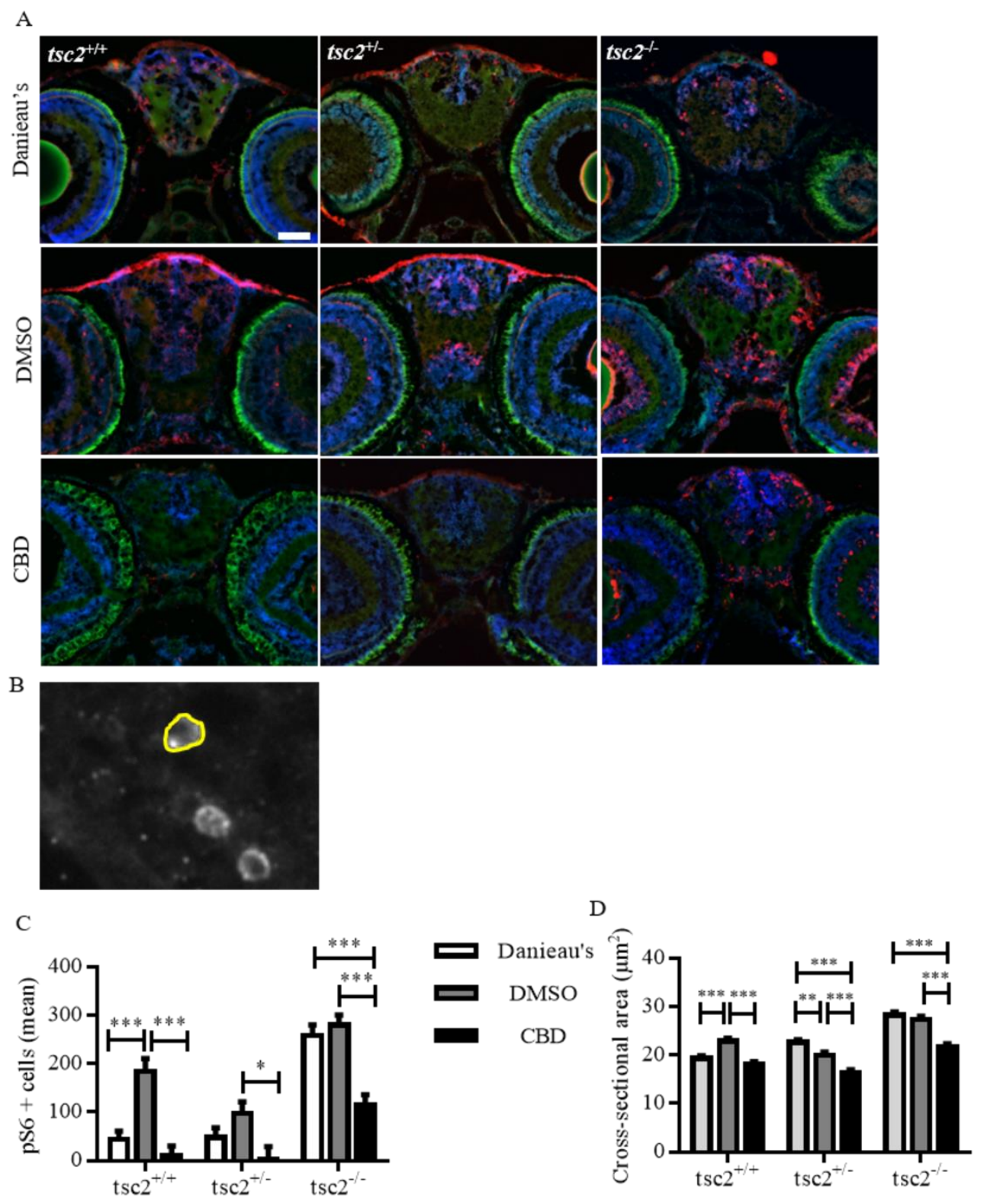

828 Figure 4: CBD reduces the number and size of phosphorylated rpS6 (Ser235/236) positive cells. (A)

829 Representative pictures of the forebrain of Danieau's, 0.1\% DMSO and CBD incubated larvae. Blue represents

830 DAPI, green tissue autofluorescence and red phosphorylated rpS6 (Ser235/236) positive cells. (C)

831 Quantification of the number of phosphorylated rpS6 (Ser235/236) positive cells in larval brain sections. 0.1\%

832 DMSO incubation increased the number of phosphorylated rpS6 (Ser235/236) positive cells in the $t s c 2^{+/+}$group.

833 CBD reduced the number of positive cells in all genotypes compared to $0.1 \%$ DMSO but only in the $t s c 2^{-1-}$

834 group, compared to the Danieau's incubated larvae $(\mathrm{F}(4,44)=3.14, \mathrm{p}=0.02 ; \mathrm{n}=3-9$ sections analysed, from 3-4

835 animals per group). (B) Magnification of a $0.1 \%$ DMSO-treated $t s c 2^{+/+}$brain section exemplifying how the

836 cross-sectional area of phosphorylated rpS6 (Ser235/236) positive cells was measured. (D) CBD incubation 
837 induced a reduction of the average cross-sectional area of phosphorylated rpS6 (Ser235/236) positive cells in all 838 genotypes, compared to $0.1 \%$ DMSO $(\mathrm{F}(4,1050)=9.06, \mathrm{p}<0.001 ; \mathrm{n}=77-115$ cells per genotype and treatment 839 from 3-4 animals per group). Values are shown as mean \pm SEM. $* * * p<0.001, * p<0.05$. Scale $=50 \mu \mathrm{m}$.

840

841 